\title{
Andrzej Jaki*
}

\section{Zofia Gródek-Szostak ${ }^{* *}$}

Uniwersytet Ekonomiczny w Krakowie

\section{WYBRANE PROBLEMY EFEKTYWNOŚCI FINANSOWANIA SIECI WSPARCIA INNOWACJI ZE ŚRODKÓW PUBLICZNYCH ${ }^{\star * *}$}

\begin{abstract}
Streszczenie
Sieci wsparcia procesów innowacyjnych stanowią nieodłączny element zarówno międzynarodowego, jak i krajowego systemu wsparcia innowacji. Systemowe tworzenie sprzyjającego klimatu dla generowania i dyfuzji innowacji wymaga zaangażowania środków pochodzących ze źródeł publicznych, w tym funduszy strukturalnych UE. Artykuł zawiera ogólną charakterystykę wybranych sieci wsparcia innowacji wraz z charakterystyką uwarunkowań efektywności ich finansowania.
\end{abstract}

Słowa kluczowe: innowacje, wsparcie publiczne, współpraca, efektywność

*Adres e-mail: jakia@uek.krakow.pl.

** Adres e-mail: zofia.grodek@gmail.com.

*** Publikacja sfinansowana ze środków przyznanych Wydziałowi Zarządzania Uniwersytetu Ekonomicznego w Krakowie w ramach dotacji na utrzymanie potencjału badawczego. 


\section{Wprowadzenie}

Wraz z rozwojem gospodarki opartej na wiedzy i innowacjach wzrasta znaczenie struktur organizacyjnych wspierających współpracę naukową (ale również przedsiębiorczą), takich jak sieci wsparcia innowacji, sieci badawcze, konsorcja naukowo-przemysłowe, regionalne i branżowe klastry. Instrumenty wsparcia kooperacji ukierunkowane są przede wszystkim na wspieranie naturalnych procesów nawiązywania współpracy między podmiotami. Oznacza to, że niezbędne jest zapewnienie odpowiedniego środowiska, w którym kooperacja przedsiębiorstw może być inicjowana w łatwy i efektywny sposób. Wsparcie publiczne w ramach funduszy strukturalnych Unii Europejskiej oraz środków Komisji Europejskiej daje możliwość finansowania tworzenia oraz funkcjonowania specjalistycznych sieci wspierających procesy innowacyjne. Potrzeba dążenia do racjonalnej alokacji funduszy publicznych uzasadnia zarazem konieczność badania efektywności wykorzystania wymienionych źródeł finansowania.

Celem niniejszego artykułu jest w związku z tym prezentacja i analiza uwarunkowań efektywności finansowania sieci wsparcia innowacji z wykorzystaniem środków publicznych ze szczególnym uwzględnieniem funduszy strukturalnych Unii Europejskiej w perspektywie 2007-2013. Artykuł został oparty na analizie i ocenie literatury ukazującej istotę kategorii efektywności ekonomicznej - w tym efektywności związanej z wydatkowaniem środków publicznych. W warstwie badawczej wykorzystano indywidualny wywiad pogłębiony z przedstawicielem instytucji centralnej i regionalnej odpowiedzialnej za programowanie lub wdrażanie analizowanych działań wspierających skierowanych do instytucji otoczenia biznesu, jak również wywiad z przedstawicielem instytucji, korzystającej ze wsparcia w ramach Programu Operacyjnego Kapitał Ludzki.

\section{Koncepcja efektywności w naukach ekonomicznych}

Efektywność jest jedną z najczęściej stosowanych kategorii w ekonomii i naukach o zarządzaniu, a przez swój interdyscyplinarny charakter także często krańcowo różnie interpretowaną i definiowaną. Sposób definiowania pojęcia efektywności zależy w dużej mierze od obszaru jego stosowania, a wraz z rozwojem wiedzy ulega ciągłej ewolucji (Ziębicki, 2013, s. 37). Efektywna działalność prowadzona 
w jakiejkolwiek dziedzinie to taka, która przynosi długookresowe korzyści osobie lub instytucji ją prowadzącej (Grzesiak, 1996, s. 54-55; Zieleniewski, 1979, s. 236). Równocześnie efektywność jest utożsamiana najczęściej z pozytywnym rezultatem podejmowanych działań oraz pozytywną (dodatnią) oceną wykorzystywanych w ich toku metod i narzędzi, służących realizacji przyjętych celów, co odróżnia ją od nieefektywności'. Wynika z tego, że kategorii efektywności nie należy utożsamiać wyłącznie z zagadnieniami gospodarczymi. Może się ona odnosić do wszystkich sytuacji, gdy podejmowane są zorganizowane działania zorientowane na realizację określonego zamierzenia (Jaki, 2012, s. 123). W przypadku przedsiębiorstw związane jest to z wykorzystywaniem różnych postaci celowo dobranych i odpowiednio zorganizowanych zasobów gospodarczych, co stanowi naturalny atrybut przedsiębiorstwa jako kategorii ekonomicznej.

Rozpatrując kategorię efektywności na gruncie nauk o zarządzaniu, należy w pierwszej kolejności zwrócić uwagę na jej ścisłe powiązanie z realizacją celów organizacji (Godziszewski, Haffer, Stankiewicz, Sudoł, 2011, s. 122; Krzyżanowski, 1994, s. 180). Cel każdej organizacji może być wyrażany zarówno rzeczowo, jak i finansowo, jest to zatem zmienna ekonomiczna odnosząca się do działalności danej organizacji, która jest przedmiotem głównego zainteresowania kierownictwa tejże i tym samym stanowi główne kryterium wyboru typu i kierunku działania (Balcerowicz, 1997, s. 111). Stąd z pojęciem celu związana jest zawsze antycypacja działalności, pod tym pojęciem kryją się bowiem przewidywane do zrealizowania zamierzenia, ukierunkowane na zaspokojenie potrzeby, która legła u podstaw realizacji przyjętego celu (Duraj, 2000, s. 52-53).

Wyjaśniając istotę i atrybuty efektywności z perspektywy jej postrzegania przez nauki ekonomiczne, należy zwrócić uwagę na istnienie ścisłego powiązania tej kategorii z kategorią racjonalności, ponieważ to efektywność ekonomiczna jest w sposób najpełniejszy wyrazicielem rezultatów racjonalności gospodarowania (Chomątowski, 1993, s. 85). Prowadzi to do wniosku, że pomiędzy tymi obydwoma kategoriami istnieje dwukierunkowa zależność. Efektywność ekonomiczna jest $\mathrm{z}$ jednej strony celem racjonalnego gospodarowania. $\mathrm{Z}$ drugiej zaś strony warunkiem uzyskania pożądanego poziomu efektywności ekonomicznej jest kierowanie

\footnotetext{
${ }^{1}$ Niezależnie od sformułowanego ogólnego sposobu rozumienia kategorii efektywności spotyka się także wykorzystywanie jej dla określenia każdego rezultatu podejmowanych działań, który może skutkować dodatnim bądź ujemnym poziomem efektywności.
} 
się podstawowymi zasadami racjonalnego gospodarowania. W tym kontekście pojawia się problem interpretacji efektywności na gruncie prakseologii jako ogólnej nauki o racjonalnym działaniu, określanej także mianem logiki racjonalnego działania (Kurnal, 1969, s. 88; Piłejko, 1976, s. 106). Sformułowana przez Oskara Langego prakseologiczna zasada racjonalnego gospodarowania (Lange, 1978, s. 147) stanowi koncepcyjną podstawę dla ekonomizacji działań, czyli wzrostu poziomu gospodarności (ekonomiczności) funkcjonowania każdej organizacji. Odbywać się to może przy wykorzystaniu trzech dróg zwiększania ekonomiczności: wariantu wydajnościowego - maksymalizacja efektu działania; wariantu oszczędnościowego - minimalizacja nakładów; wariantu wydajnościowo-oszczędnościowego - maksymalizacja efektu działania, przy równoczesnym dążeniu do minimalizacji niezbędnych do poniesienia nakładów (Tyrańska, 2010, s. 154).

\section{Efektywność wydatkowania środków publicznych}

Efektywność wydatkowania środków publicznych oznacza rezultaty podejmowanych działań opisanych relacją efektów do poniesionych nakładów (Guziejewska, 2008, s. 72), przy czym relacja ta powinna dążyć do optimum. Efektywność w odniesieniu do realizacji zadań publicznych jest rozumiana jako zbiór relacji ekonomicznych w postaci przepływów pieniężnych pomiędzy uczestnikami działalności służącej realizacji zadań wyznaczonych prawem i zależy w znacznej mierze od trafności doboru oraz prawidłowości skonstruowania instrumentów pieniężnych, dzięki którym realizowane są procesy podziału i wymiany wytworzonych dóbr i usług (Sochacka-Krysiak, 2009, s. 192).

Ocena efektywności wydatkowania środków pochodzących ze źródeł publicznych wskazuje na konieczność opracowania i wykorzystywania jasno sprecyzowanych standardów i mierników działalności i realizacji zadań oraz wykorzystania narzędzi kontrolnych, w szczególności w odniesieniu do standardów i mierników działalności i realizacji zadań. Niezbędne jest zatem nie tylko dokonywanie pomiarów, lecz także przeprowadzenie wartościowania ich wyników (Filipiak, 2010). Stanowi to podstawę oceny efektów, którą można powiązać z efektywnością i oceną skuteczności podejmowanych działań. Tak więc nowe zarządzanie publiczne promuje ideę tzw. 3E, czyli ocenę gospodarności (economy), wydajności (efficiency) oraz skuteczności (effectiveness). Należy też podkreślić, że efekty niektórych 
wydatków publicznych występują po wielu latach, powodując brak precyzyjnego rozkładu w czasie nakładów i efektów, co jest podstawowym warunkiem pomiaru efektywności (Poniatowicz, Salachna, Perło, 2010, s. 49).

Wstępne oceny dotyczące efektywności wykorzystania środków publicznych pochodzących z funduszy strukturalnych są pesymistyczne, tylko część środków wydawana jest w taki sposób, że przyczynia się do trwałego rozwoju. Przyczyną powyższego stanu jest nieefektywność i niewydolność systemu wydatkowania środków będąca konsekwencją przerostu liczby i jakości regulacji prawnych (Kozioł-Nadolna, 2016, s. 137-138; Mäntymäki, Riemer, 2016). Analiza raportów z badań oceny skuteczności wsparcia sieci wsparcia innowacji wskazuje na wykorzystywanie narzędzi pomiaru i wartościowania wyników efektywności w postaci zogniskowanych wywiadów grupowych, wywiadów osobistych wspomaganych komputerowo (CAPI) prowadzonych wśród klientów usług sieciowych (PARP, 2016, s. 14-15).

Przedstawiony przegląd literatury nie wyczerpuje złożoności zagadnienia efektywności. Wraz z rozwojem gospodarczym i społecznym podejmowane są kolejne dyskusje, odnoszące się także do szczególnych uwarunkowań efektywności, z czym mamy m.in. do czynienia w przypadku wykorzystania funduszy publicznych jako źródeł finansowania innowacji.

\section{Enterprise Europe Network i Krajowy System Usług jako sieci wsparcia innowacji}

W gospodarce opartej na wiedzy coraz większego znaczenia dla wzrostu aktywności gospodarczej i przewagi konkurencyjnej przedsiębiorstw nabiera otoczenie i szeroko rozumiana współpraca (Ratajczak-Mrozek, 2009). Dzięki pracy zespołów eksperckich tworzą się sieci wyspecjalizowanych instytucji wspierania przedsiębiorczości, innowacyjności i transferu technologii (tab. 1).

Sieć Enterprise Europe Network (EEN) została utworzona jako element wdrażania Programu Ramowego na rzecz Konkurencyjności i Innowacji 2007-2013, a w latach 2014-2020 finansowana w ramach Programme for the Competitiveness of Enterprises and Small and Medium-sized Enterprises (COSME). Ośrodki sieci są prowadzone przez rozmaite organizacje wspierające rozwój gospodarczy, takie jak izby gospodarcze i przemysłowo-handlowe, agencje rozwoju regionalnego, centra wspierania przedsiębiorczości, centra transferu technologii itp. Głównym celem 
Tabela 1. Sieci informacyjne dla przedsiębiorstw

\begin{tabular}{|c|c|c|}
\hline \multirow{2}{*}{$\begin{array}{l}\text { Sieci o zasięgu } \\
\text { europejskim }\end{array}$} & \multicolumn{2}{|c|}{ Sieci o zasięgu krajowym } \\
\hline & bez struktur regionalnych & ze strukturami regionalnymi \\
\hline Europe Direct (ED) & Krajowy System Usług (KSU) & $\begin{array}{l}\text { Lokalne Okienka Przedsiębiorczości } \\
\text { (LOP) }\end{array}$ \\
\hline $\begin{array}{l}\text { Enterprise Europe } \\
\text { Network (EEN) }\end{array}$ & Krajowa Sieć Innowacji (KSI) & $\begin{array}{l}\text { Regionalne Instytucje Finansujące } \\
\text { (RIF) }\end{array}$ \\
\hline $\begin{array}{l}\text { Krajowy Punkt } \\
\text { Kontaktowy Programów } \\
\text { Badawczych Unii } \\
\text { Europejskiej (KPK) }\end{array}$ & $\begin{array}{l}\text { Akademickie Inkubatory } \\
\text { Przedsiębiorczości (AIP) }\end{array}$ & $\begin{array}{l}\text { Regionalne Ośrodki Europejskiego } \\
\text { Funduszu Społecznego (ROEFS) }\end{array}$ \\
\hline EuroInfoCentres (EIC) & $\begin{array}{l}\text { Krajowa Izba Gospodarcza } \\
\text { (KIGNET) }\end{array}$ & $\begin{array}{l}\text { Regionalne Centrum Informacji } \\
\text { Europejskiej (RCIE) }\end{array}$ \\
\hline $\begin{array}{l}\text { Europejska Sieć Aniołów } \\
\text { Biznesu (EBAN) }\end{array}$ & $\begin{array}{l}\text { Krajowa Sieć Obszarów } \\
\text { Wiejskich (KSOW) }\end{array}$ & $\begin{array}{l}\text { Regionalne Fundusze Pożyczkowe } \\
\text { (RFP) }\end{array}$ \\
\hline $\begin{array}{l}\text { FINancial Services } \\
\text { Complaints NETwork } \\
\text { (FIN-NET) }\end{array}$ & $\begin{array}{l}\text { Ogólnopolska Sieć Transferu } \\
\text { Technologii i Wsparcia } \\
\text { Innowacyjności MŚP (STIM) }\end{array}$ & $\begin{array}{l}\text { Regionalne Centra Informacyjne } \\
(\text { FEM) }\end{array}$ \\
\hline
\end{tabular}

Źródło: Gródek (2010), s. 206.

sieci jest oferowanie małym i średnim przedsiębiorstwom kompleksowych usług służących zwiększeniu ich potencjału oraz zdolności innowacyjnych. Usługi EEN świadczone są w trzech zakresach:

1. Usługi informacyjne z zakresu prawa i polityk UE oraz pomoc w znalezieniu partnerów biznesowych.

2. Usługi w zakresie transferu technologii.

3. Usługi informacyjne z zakresu Programu HORIZON 2020.

Dla skutecznej działalności sieci istotna jest współpraca między ośrodkami z różnych krajów, są one zobowiązane do odpowiadania na zapytania przedsiębiorców, przekazywane im przez zagraniczne ośrodki.

Zadania sieci realizowane są przez ośrodki rozmieszczone w całej Unii Europejskiej oraz wielu innych krajach. Ośrodki tworzą konsorcja regionalne operujące na określonym terenie. W sensie formalnym każde konsorcjum realizuje osobny projekt EEN. Z projektową organizacją sieci związana jest obecność lidera (organizacji wiodącej), który koordynuje prace konsorcjum, odpowiada za właściwą realizację projektu, zajmuje się administracją oraz komunikuje się z Komisją Europejską zarządzającą siecią. Współpraca polskich ośrodków EEN odbywa się przede 
wszystkim w ramach konsorcjów oraz w układach międzynarodowych. Współpraca w ramach konsorcjum jest niejako oczywista i wiąże się z realizacją wspólnego projektu, czyli sprawozdawczością, wskaźnikami, wykonywaniem wspólnych działań oraz przepływami finansowymi między liderem i partnerami. Kooperacja międzynarodowa wynika z założeń sieci EEN, która ma stymulować transgraniczną współpracę przedsiębiorstw i takiż transfer technologii.

W opinii przedstawicieli sieci EEN jej efektywność jest oceniana wysoko. Podkreślają oni, że proces łączenia starych sieci i rozruchy projektu EEN wpłyną na okresowe zmniejszenie aktywności ośrodków, które musiały się dostosować do nowych uwarunkowań działania. Przedstawiciele ośrodków EEN, porównując je do ośrodków zagranicznych, dostrzegają nieco mniejszą efektywność polskich ośrodków, zwłaszcza w przypadku najważniejszych, najbardziej namacalnych efektów, którymi są umowy między partnerami biznesowymi oraz transgraniczne transfery technologii. W opinii konsultantów EEN wynika to przede wszystkim z mniejszego potencjału polskich firm, ale także instytucji naukowych (które mogą za pośrednictwem sieci oferować swoje usługi i technologie).

Krajowy System Usług (KSU) dla małych i średnich przedsiębiorstw tworzą działające w Polsce organizacje wyspecjalizowane w świadczeniu różnego rodzaju usług dla przedsiębiorstw i osób podejmujących działalność gospodarczą. Członkowie KSU są niezależni i samofinansujący się, a uczestnictwo w systemie jest dobrowolne. Spełnienie wymogów i rejestracja w systemie uprawniają do posługiwania się nazwą i logo KSU. Sama rejestracja w KSU nie przekłada się jednak na dostęp do finansowania, tzn. ośrodki KSU nie otrzymują żadnych środków finansowych na działalność z tytułu rejestracji w systemie. Rejestracja jest potwierdzeniem spełnienia kryteriów, co w domyśle przekłada się na gwarancję jakości usług. Podsystemy KSU zdefiniowane przez cztery rodzaje usług systemowych (informacyjne, doradcze, szkoleniowe i finansowe) w założeniu wzajemnie się dopełniają (tab. 2).

W latach 2007-2015 usługi KSU były finansowane w ramach realizacji projektu systemowego PARP „Zapewnienie dostępu przedsiębiorstw do nowych usług KSU", finansowanego w ramach Poddziałania 2.2.1 Programu Operacyjnego Kapitał Ludzki na lata 2007-2013 (tab. 3). 
Tabela 2. Zakres usług realizowany przez KSU

\begin{tabular}{|c|c|}
\hline Usługi doradcze & Usługi informacyjne \\
\hline $\begin{array}{l}\text { - charakterze ogólnym, np. w dziedzinie } \\
\text { marketingu, finansów, prawa, planowania } \\
\text { i zarządzania, eksportu, jakości itp. } \\
\text { - o charakterze proinnowacyjnym, służące } \\
\text { rozwojowi firmy poprzez poprawę ist- } \\
\text { niejącego lub wdrożenie nowego procesu } \\
\text { technologicznego, produktu lub usługi }\end{array}$ & $\begin{array}{l}\text { - administracyjno-prawne aspekty prowadzenia } \\
\text { działalności gospodarczej } \\
\text { - o dostępnych programach pomocy publicznej } \\
\text { dla przedsiębiorców oraz innych dostępnych } \\
\text { źródłach finansowania działalności gospodarczej } \\
\text { - przygotowanie wniosków o pomoc publiczną } \\
\text { i finansowanie działalności gospodarczej z innych } \\
\text { źródeł } \\
\text { - wprowadzanie informacji o ofercie handlowej } \\
\text { do baz danych służących nawiązaniu współpracy } \\
\text { gospodarczej (w tym zagranicznej) } \\
\text { - wyszukiwanie potencjalnych partnerów } \\
\text { gospodarczych w dostępnych bazach danych } \\
\text { (w tym weryfikowalnych przez wywiadownie } \\
\text { gospodarcze) }\end{array}$ \\
\hline Usługi finansowe & Usługi szkoleniowe \\
\hline $\begin{array}{l}\text { - udzielanie poręczeń kredytowych stano- } \\
\text { wiących dodatkową formę zabezpieczenia } \\
\text { głównie kredytów i pożyczek (fundusze } \\
\text { poręczeniowe) } \\
\text { - udzielanie pożyczek na rozpoczęcie } \\
\text { lub rozwój działalności gospodarczej }\end{array}$ & $\begin{array}{l}\text { - } \text { szkolenia otwarte, w których uczestnictwo jest } \\
\text { ogólnie dostępne } \\
\text { - szkolenia zamknięte, organizowane na } \\
\text { indywidualne zamówienie klienta }\end{array}$ \\
\hline
\end{tabular}

Źródło: opracowanie własne na podstawie PARP (2008).

Tabela 3. Usługi systemowe Krajowego Systemu Usług

\begin{tabular}{|c|c|}
\hline $\begin{array}{l}\text { Instrument wsparcia/ } \\
\text { nazwa usługi }\end{array}$ & Charakter usługi \\
\hline 1 & 2 \\
\hline $\begin{array}{l}\text { Usługa pilotażowa } \\
\text { w zakresie wykorzysta- } \\
\text { nia technologii infor- } \\
\text { macyjnych w zarządza- } \\
\text { niu przedsiębiorstwem }\end{array}$ & $\begin{array}{l}\text { Usługa audytowo-doradcza składająca się z dwóch etapów: } \\
\text { etap I - audyt systemu organizacji i zarzązania w przedsiębiorstwie } \\
\text { oraz wykorzystywanych technologii informacyjnych } \\
\text { etap II - doradztwo we wdrażaniu rekomendacji wynikających z audytu } \\
\text { oraz szkolenie }\end{array}$ \\
\hline $\begin{array}{l}\text { Usługa pilotażowa } \\
\text { w zakresie zarządzania } \\
\text { efektywnością } \\
\text { energetyczną } \\
\text { przedsiębiorstw }\end{array}$ & $\begin{array}{l}\text { Usługa doradczo-szkoleniowa składająca się z dwóch etapów: } \\
\text { etap I - } \\
\text { audyt energetyczny polegający na analizie stanu gospodarki } \\
\text { energetycznej przedsiębiorstwa, w celu identyfikacji } \\
\text { możliwych do wdrożenia działań zmierzających do zwiększenia } \\
\text { efektywności energetycznej w tym przedsiębiorstwie } \\
\text { etap II - } \\
\text { doradztwo we wdrażaniu rekomendacji wynikających } \\
\text { z audytu energetycznego ukierunkowanych na podniesienie } \\
\text { efektywności energetycznej przedsiębiorstwa o co najmniej 5\% }\end{array}$ \\
\hline
\end{tabular}




\begin{tabular}{|c|c|}
\hline 1 & 2 \\
\hline $\begin{array}{l}\text { Usługa pilotażowa } \\
\text { w zakresie marketingu } \\
\text { i sprzedaży produktów } \\
\text { dla mikro i małych } \\
\text { przedsiębiorstw } \\
\text { z branży przetwórstwa } \\
\text { rolno-spożywczego }\end{array}$ & $\begin{array}{l}\text { Usługa składająca się z dwóch komponentów: } \\
\text { komponent I podzielony na } 3 \text { etapy: } \\
\text { etap I - } \quad \begin{array}{l}\text { audyt marketingowy polegający na szczegółowej analizie } \\
\text { sytuacji rynkowej klienta, stanowi podstawę do zbudowania } \\
\text { zindywidualizowanego planu marketingowego }\end{array} \\
\text { etap II - } \begin{array}{l}\text { doradztwo strategiczne polegające na przeprowadzeniu } \\
\text { indywidualnego doradztwa, którego rezultatem jest } \\
\text { opracowany plan marketingowy oraz } 5 \text { wykonawczych } \\
\text { programów marketingowych zapisanych w formie } \\
\text { praktycznych działań }\end{array} \\
\text { etap III - asysta we wdrażaniu planu marketingowego i wykonawczych } \\
\text { programów marketingowych } \\
\text { Komponent II - szkolenie dotyczące podstawowych zagadnień z zakresu } \\
\text { marketingu, budowania planu marketingowego w branży przetwórstwa } \\
\text { rolno-spożywczego, wdrażania planu we własnym przedsiębiorstwie } \\
\text { i zasad monitorowania jego realizacji }\end{array}$ \\
\hline $\begin{array}{l}\text { Usługa systemowa } \\
\text { w zakresie ochrony } \\
\text { środowiska }\end{array}$ & $\begin{array}{l}\text { Usługa szkoleniowo-doradcza składająca się z trzech etapów: } \\
\text { etap I - } \\
\quad \text { audyt środowiskowy, identyfikacji stopnia spełniania } \\
\text { etap II - } \\
\quad \text { wsparcie doradcze przy wdrażaniu działań rekomendowanych } \\
\text { w etapie I } \\
\text { etap III - } \\
\text { szkolenia z zakresu wykorzystania narzędzi pozwalających } \\
\text { na obliczanie poziomu korzystania ze środowiska oraz na } \\
\text { obliczanie opłat za korzystanie ze środowiska }\end{array}$ \\
\hline
\end{tabular}

Źródło: opracowanie własne.

Krajowy System Usług koordynowany jest przez Polską Agencję Rozwoju Przedsiębiorczości (PARP). Misją KSU jest „rozwój przedsiębiorczości poprzez zapewnienie najwyższej jakości usług w kluczowych obszarach wymagających wsparcia państwa”.

\section{Podsumowanie}

Istotnym zagadnieniem z punktu widzenia efektywności wykorzystania środków publicznych wydaje się rola władz publicznych w kreowaniu i działaniu sieci organizacji wspierających innowacyjność i transfer technologii. W przypadku przedstawionych w artykule sieci EEN i KSU znaczenie władz publicznych było kluczowe. Wszystkie sieci były finansowane ze środków publicznych w ramach specjalnych programów, jednak efekty poszczególnych inicjatyw okazywały się zróżnicowane. Zatem zapewnienie wysokiej jakości podejmowanych działań oraz ich 
skuteczności jest istotnym obszarem dla inicjatywy władz publicznych. Wsparcie dla sieci musi być precyzyjnie zaplanowane, szczególnie w zakresie celu działania sieci oraz mechanizmów współpracy. Jeżeli współpraca w sieci nie ma potencjału synergicznego, to zazwyczaj takie same cele można osiągnąć efektywniej (a przede wszystkim taniej) bez tworzenia struktury sieciowej (Ratajczak-Mrozek, 2010 s. 29-41). Instytucje odpowiedzialne za tworzenie programów i projektów rozwojowych na poziomie krajowym oraz regionalnym powinny mieć na uwadze, że sieci nie są cudownym rozwiązaniem, ich tworzenie nie zawsze musi być efektywne i co wydaje się kluczowe - nie zawsze jest konieczne.

Zapewnienie wysokiej jakości podejmowanych działań oraz ich skuteczności jest istotnym obszarem dla inicjatywy władz publicznych. Wsparcie dla sieci musi być precyzyjnie zaplanowane, szczególnie w zakresie celu działania sieci oraz mechanizmów współpracy. Współpraca dla samej współpracy nie powinna być celem sieci finansowanych ze środków publicznych, ponieważ po zakończeniu finansowania publicznego nie udaje się zbudować trwałej sieci współpracy. Rekomendacje dla decydentów obejmują następujące płaszczyzny decyzyjne: utrzymania sieci dostępnych w całym kraju instytucji oferujących przedsiębiorcom podstawowe wsparcie informacyjne i doradcze; wspierania instytucji otoczenia biznesu zarówno ze szczebla krajowego, jak i regionalnego, z jednoczesnym doskonaleniem komplementarności wsparcia pomiędzy obydwoma poziomami; wprowadzanie ograniczonej odpłatności za usługi powinno być upowszechniane, jednak z ograniczeniami wobec najsłabszych i najmniej zasobnych odbiorców wsparcia.

\section{Literatura}

Balcerowicz, L. (1997). Socjalizm. Kapitalizm. Transformacja. Szkice z przełomu epok. Warszawa: Wydawnictwo Naukowe PWN.

Chomątowski, S. (1993). Dynamika rozwoju a efektywność systemów przemysłowych. Zeszyty Naukowe Akademii Ekonomicznej w Krakowie. Monografie, 115, 1-218.

Duraj, J. (2000). Podstawy ekonomiki przedsiębiorstwa. Warszawa: PWE.

Filipiak, B. (2010). Zarządzanie finansami jako podstawa nowoczesnej gospodarki finansowej jednostek samorządu terytorialnego. Zeszyty Naukowe Wyższej Szkoty Bankowej w Poznaniu, 31, 43-52. 
Godziszewski, B., Haffer, M., Stankiewicz, M.J., Sudoł, S. (2011). Przedsiębiorstwo. Teoria i praktyka zarzadzania. Warszawa: PWE.

Gródek, Z. (2010). Sieci informacyjne dla przedsiębiorczości - czynnik przewagi konkurencyjnej opartej na informacji. W: R. Borowiecki, J. Czekaj (red.), Zarzadzanie zasobami informacyjnymi w warunkach nowej gospodarki (s. 202-211). Warszawa: Difin.

Grzesiak, S. (1996). Efektywność funkcjonowania przedsiębiorstw - aspekty prakseologiczne i ekonomiczne. W: Przedsiębiorstwo na rynku. Tom 1: Gospodarka polska w procesie transformacji systemowej (cz. 1). Materiaty - Konferencje nr 17 (s. 51-63). Szczecin: Wydawnictwo Naukowe Uniwersytetu Szczecińskiego.

Guziejewska, B. (2008). Efektywność finansów samorządu terytorialnego. Gospodarka Narodowa, 5-6, 71-89.

Jaki, A. (2012). Mechanizmy procesu zarządzania wartościa przedsiębiorstwa. Kraków: Wydawnictwo Uniwersytetu Ekonomicznego w Krakowie.

Kozioł-Nadolna, K. (2016). Analiza wpływu środków UE na innowacyjność polskich przedsiębiorstw. W: D. Rosati, J. Wiśniewska (red.), Działalność innowacyjna przedsiębiorstw w Polsce - dylematy i sposoby wspierania środkami Unii Europejskiej (s. 129-141). Warszawa: Wydawnictwo CeDeWu.

Krzyżanowski, L. (1994). Podstawy nauk o organizacji i zarzadzaniu. Warszawa: Wydawnictwo Naukowe PWN.

Kurnal, J. (1969). Zarys teorii organizacji i zarządzania. Warszawa: PWE.

Lange, O. (1978). Ekonomia polityczna. Tom 1. Warszawa: PWN.

Mäntymäki, M., Riemer, K. (2016). Enterprise social networking: A knowledge management perspective. International Journal of Information Management, 36 (6/A), 1042-1052.

PARP (2008). Przedsiębiorco! Skorzystaj! Warszawa: PARP.

PARP (2016). Raport końcowy. Badanie klientów i ustugodawców systemowej ustugi Krajowego Systemu Ustug $w$ zakresie szybkiej optymalizacji zarzadzania finansami przedsiębiorstwa. Warszawa: PARP.

Piłejko, K. (1976). Prakseologia - nauka o sprawnym działaniu. Warszawa: PWN.

Poniatowicz, M., Salachna, J.M., Perło, D. (2010). Efektywne zarzadzanie dtugiem w jednostce samorzadu terytorialnego. Warszawa: Wolters Kluwer.

Ratajczak-Mrozek, M. (2009). Sieci biznesowe na tle innych koncepcji kooperacji przedsiębiorstw. Gospodarka Narodowa, 7-8, 79-91.

Ratajczak-Mrozek, M. (2010). Sieci biznesowe a przewaga konkurencyjna przedsiębiorstw zaawansowanych technologii na rynkach zagranicznych. Poznań: Wydawnictwo Uniwersytetu Ekonomicznego w Poznaniu. 
Sochacka-Krysiak, H. (2009). Niektóre problemy efektywności w gospodarce finansowej samorządu terytorialnego. W: S. Wieteska, M. Wypych (red.), W poszukiwaniu efektywności finansów publicznych (s. 191-198). Łódź: Wydawnictwo Uniwersytetu Łódzkiego.

Tyrańska, M. (2010). Determinants of management effectiveness. W: R. Borowiecki, A. Jaki (red.), Enterprises Facing New Economic Challenges. Management - Development Restructuring. Cracow: Cracow University of Economics - Foundation of the Cracow University of Economics.

Zieleniewski, J. (1979). Organizacja i zarzadzanie. Warszawa: PWN.

Ziębicki, B. (2013). Efektywność w naukach ekonomicznych. Biuletyn Ekonomii Społecznej. Kraków: Fundacja Gospodarki i Administracji Publicznej.

\title{
SELECTED PROBLEMS OF THE EFFECTIVENESS OF FINANCING INNOVATION NETWORK SUPPORT FROM PUBLIC FUNDS
}

\begin{abstract}
Support networks of innovative processes are an integral part of both the international and the national system of innovation support. System to create a favourable climate for the generation and diffusion of innovation requires a commitment of resources from public sources, including the EU structural funds. The article contains a general description of selected networks to support innovation and the characteristics of the effectiveness of their financing.
\end{abstract}

Keywords: innovation, public support, cooperation, effectiveness

JEL codes: O14, O11 